\title{
Education and Social Exclusion of Children With Chronic Diseases: The Case of Schooling Within Greek Hospitals
}

\author{
Vassiliki Kontogianni \\ Stratigou Gennadiou 9, Thessaloniki, 54248, Greece \\ E-mail: vkontogianni@outlook.com
}

Christos Tourtouras

Department of Elementary Education, Aristotle University of Thessaloniki, Greece

E-mail: htourt@eled.auth.gr

Argyris Kyridis (Corresponding author)

School of Early Childhood Education, Aristotle University of Thessaloniki, Greece

E-mail: akiridis@nured.auth.gr

Eleni Pehlivanou

Diavatos, Veria, 59033, Greece

E-mail: elenipehlivanos@gmail.com

Received: March 14, 2021

doi: 10.5296/ire.v9i1.18599
Accepted: May 28, $2021 \quad$ Published: May 30, 2021

URL: https://doi.org/10.5296/ire.v9i1.18599

\begin{abstract}
This research attempts to identify effective teaching strategies, as well as any barriers encountered in the education of children with chronic diseases. In addition, it attempts to probe the conditions under which the children are being taught after hospitalization. The research data was collected after a series of interviews with parents whose children had been
\end{abstract}


hospitalized for a long time with a serious illness and teachers who had worked in hospital schools or had received a child after hospitalization. The findings of the study show that hospital education has gaps in curriculum content and that significant government attention is needed on program and material infrastructure issues. It also emphasizes the inadequate training of teachers about chronic diseases as well as the approach of children who are reintegrated into school life after a long absence.

Keywords: Social exclusion, Chronic diseases, Hospital education, Pediatric cancer

\section{Introduction}

This research is referred to the specific educational regime under which the students with chronic diseases are submitted and probably excluded from the educational system. By chronic disease we mean the disease that does not have an immediate cure and does not necessarily lead to the passing of the patient. It requires frequent hospital visits and medical interventions, while long-term treatment can be debilitating for the sufferer (Kaffenberger, 2006). As for children suffering from chronic illnesses, they are affected in various areas of their daily lives such as their appearance and functionality. One of the problems that these children and their families have to face with, is to continue some of their daily activities such as schooling. A review on the bibliography on childhood cancer, in general, found a large number of psychological studies assessing the effects of the disease on the child, using mainly standard quantitative tools. However, in recent years there has been a development of a variety of interdisciplinary approaches, such as anthropological or sociological, that also use qualitative research tools (Dixon-Woods et al., 2005).

Chronic disease often leads to social exclusion of those who suffer from it. Indicatively, we mention the case of the excluded communities of lepers during the Byzantine -and not onlyperiod, under the pretext of protecting public health. Marginalization, however, by society as a whole, negatively affects health and sometimes leads to premature death (DeWall et al., 2011). Social exclusion, as a state and process, is linked to politics, economics, education, and every sector of social life. The term appeared in the 1970s in France and referred to those who were excluded from the social welfare and economic life system (Arabatzi \& Tourtouras, 2015). Usually, social exclusion is connected solely with the concept of poverty and is discussed at the level of, basically, economic analyses (Tourtouras, 2017).

Bäckman and Nilsson (2011) argue that social exclusion is a process in which individuals or groups are unable to fully participate in society because of their unemployment, limited skills, poverty and poor health. Pleios (1998) defines social exclusion as a state of absence, mainly of social, but also, of political or individual rights. For the discussion of the economy in this article, we adopt the definition given by Tsiakalos, which states:

"Social exclusion is the impediment to the gaining of social and public goods, such as e.g. those of education, the health care system, political participation, etc., the lack of which usually leads to economic hardship" (Tsiakalos, 2008: 184).

Similarly, educational exclusion is to prevent a person from accessing the social and public good of education, which, in fact, is based on existing inequalities in education and society at 
large and, in terms, subsequently exacerbates them. Moreover, one can see the hardship on the school career of Roma children, children from culturally and ethnically different minorities (immigrants, refugees, etc), children from the lower social classes of the society, children with disabilities, and from other minority populations. In Kyridis (1996; 2003) and in Kyridis et al. (2011), we read that the concept of equal opportunities refers to the provision of access to every level of the educational network and the possibility of offering all of its provided advantages for all citizens. However, within the framework of the dominant capitalistic system, and in the name of the neoliberal ideology, the notion of equality has been thoroughly distorted in a beautified, idealized view of social life, and of education as well (Thanos et al. 2017). Thus, students who are excluded in one way or another, temporarily or permanently, from education, experience dimensions of educational inequality and are confronted with an educational and professional future that seems inevitable and predetermined and could be characterized by low income, long periods of unemployment, low participation in many aspects of everyday life, etc. In general, we could say that hierarchy through education and the social categorization of individuals into "privileged and non-privileged' form the boundaries of their subsequent participation in the political issues of society.

Reversing the relationship, we also notice that any social inequality determines, at least to a point, the individual's later educational career, as Bourdieu and Passeron claim:

"We need to take into account all the social characteristics that define the initial status of children in different social classes in order to understand the different possibilities they are given by these different school destinies" (Bourdieu \& Passeron, 2014: 131).

In the case of children with chronic diseases, the long duration of hospitalization at home or in the hospital takes them away from school reality and everyday life. Therefore, the experience of chronic disease and the need for, more or less, long-term treatment may develop into a factor of educational - and further social - exclusion.

It is worth noting at this point that, according to modern research, social exclusion is directly related to the poor functioning of the immune system, poor quality sleep and increased death rates (DeWall et al., 2011). In addition, we are able to recognize that experiences of social exclusion, especially when repeated over and over again, can have a long-term effect on children and adolescents and are associated with distressful psychological conditions, such as anxiety and depression (Tobia et al., 2017). Especially, short-lived exclusion experienced by individuals seeking treatment or suffering with chronic diseases are vulnerable to the same effects of those that experience social exclusion for other reasons such as economic. Particularly, children who survive some neoplastic diseases can develop increased anxiety, have reduced social skills, fewer friends, and are characterized by low self-esteem. The above are elements that can be exacerbated by the increased school absences due to long-term treatments (French et al., 2013). It is obvious that all of the above have a negative effect on educational activities. Studies have shown that excluded or rejected children stop participating in joint classroom activities in order to avoid further negative experiences with their classmates, which ultimately leads to lower school achievements (Tobia et al., 2017). 


\subsection{EACH - Chart and Hospital Education}

In 1988, at the initiative of parents, children and medical personnel from 12 European countries, the first European Conference was held in the Netherlands for the rights of children being on long life treatment. In 1993, during the Third European Conference in Austria, the European Union for the Rights of the Hospitalized Child was founded, as a Federation of all Organizations, with the aim of offering hope, treatment and prosperity of the sick children, as well as the implementation of the provisions of the Chart (Pantazis, 2013).

The EACH Chart consists of ten articles that are considered fundamental for the well-being and caring of a sick child. Article 7, which is directly related to the present study, emphasizes the need for equal opportunities for play, recreation and education for children with chronic diseases and the provision of a properly equipped environment to meet their needs (EACH, 2019). Thus, through the realization for the need of a model to provide education and entertainment to children who are hospitalized, the institution of hospital education, has been established and is an integral part of the pediatric and pedo-oncology clinics of developed countries.

By hospital education, we mean the schooling, from early-childhood to secondary education, provided to children in the various pediatric and pedo-oncology hospitals of the country, while they are hospitalized (Patsalis \& Darladima 2013). Hospital education presents clear differences from mainstream education, as it is called to cover the educational and psycho-emotional needs of children who are hospitalized for a long time. It is considered important for these children to maintain a level of normalcy and social and educational development throughout the course of their disease (Vassilatou-Kosmidi, 2013a). Hospital education needs to include an organized program, appropriately designed rooms within the hospitals, teaching materials and preparation programs specifically designed to ease the child's return to typical school, based on a school without exclusions (Serradas Fonseca, 2018). The growing number of children being treated for chronic illnesses has created the need for in-hospital education. The continuation of the educational process is considered necessary for their physical and psychological development. The school is not only a place of learning, but also a place where relationships develop, values are established and the young person's self-confidence increases. Therefore, it is necessary to continue their education during their treatment and be guided by experienced and qualified teachers (Vassilatou-Kosmidi, 2013b).

On an international level, hospital schools have been established in recent decades and many countries have passed legislation to regulate their organization, duties and resources. In 2010, a study was published by Gerd \& Capurso (2010) in which the ministers of the 47 member states of the Council of Europe (including the administratively autonomous Swiss cantons and the German federal states) were asked about the educational services that were provided by their countries to sick children. The results of the research constituted a table, which included information on how hospital education was institutionalized in each state separately. In the end, 33 of the 47 states responded. It is noted that Greece, Italy and Spain didn't respond. 
It turns out, in general, that hospital schools have special features that differentiate them from traditional schools. As for their educational context, they are very complex and require specialized skills from educators (Benigno et al., 2018). In some countries, in hospital schools, priority is not the lessons, but the activities that relieve the children from the general tensions created by the special conditions of the hospital and the disease. It's more of a process that focuses on play and friendly discussion. Sylva mentions:

"(...) Hospital play has healing properties. Children show reduced stress before treatment, increased cooperation and a sooner discharge from the hospital, when given the opportunity to play with medical or surgical instruments (...) to a lesser extent, but yet, still effective in reducing stress, are games unrelated to hospitalization and treatment, such as simple physical exercise" (see Brouskeli, 2013: 7).

\subsection{The Student Hospitalized and the Role of Education}

One can imagine that a student with a chronic illness, such as cancer, is in an unfavorable position compared to his or her healthy peers. The diagnosis and treatment of childhood cancer has short and long-term effects on children and their families, as it affects their physical, psychological and academic development (Hay et al., 2015).

An issue that requires solving is the number of absences from school. Kaffenberger (2006) estimates that in the first year of hospitalization, children with leukemia lose about 40 days of school attendance and continue to have an inconsistent attendance over the next three years. A fact which makes the need more urgent to continue their education unhindered within the hospitals, during hospitalization. We should not ignore the fact that there are children who do not return to school -in the first year and possibly the next two after hospitalization- but receive home schooling.

The teaching conditions of a child receiving medical treatment are very different and, obviously, more difficult than those observed in a typical school, mainly due to the dramatic change of daily life, such as frequent hospitalizations, operations and unpredictable periods of recovery and deterioration that require a significant number of school absences (Boles et al., 2017). The students with cancer need support so that they do not become victims of the incompatibility of two systems (the educational and health care system) that are inadequately connected to each other (Hay et al., 2015).

Children who are treated at regular intervals -those, for example, who undergo chemotherapy- are constantly on the edge of a procedure. Continuous absences from school -and in many cases, the long absence from their return to formal education- involve risks of school failure and consequently educational exclusion. In many cases, the outcome of exhausting treatments requires further long-term isolation, making school completion even more impossible. The general sense given is that the typical educational systems and policies are not designed to lend support to students battling chronic illness (Irwin \& Elam, 2011).

\subsection{The Role of the Hospital Teacher}

The education of children, who come face to face with a chronic health problem and are 
required to spend much of their time in hospital structures, is significantly different from that of children who are part of a typical school learning routine. The whole process is a peculiarity that requires alternative ways of handling by hospital teachers and the overall medical staff. In pediatric, more specifically in pedo-oncology clinics, school space has a different meaning for children. For hospitals fortunate to have dedicated spaces for schooling, these classrooms may be the only place in the hospital where the child can "escape" for a while from the painful treatments and the confinement of an inpatient room. The hospital school can be the connecting link with the outside world. The hospital teacher can serve as a "bridge" between the family and the hospital and promote the right to education within a subtle and complicated framework (Ferrara \& Flammia, 2013).

However, teachers are not trained in their circular studies on the special requirements of the role of a hospital teacher. To be precise, the productive pedagogical departments, as shown by the analysis of their curricula, do not provide knowledge (either general or special education or psychology) to prospective hospital teachers, neither in theory nor in practice in this field (Patsalis \& Darladima, 2013). As a result, the hospital teacher is particularly concerned when faced with many major challenges during his or her tenure. First of all, a teacher must realize that his/her main goal should be to maintain the rhythm of everyday life that children, with whom he/she collaborates, used to have before their induction to the hospital (Charitos \& Kontadaki, 2013). This is important especially since the children themselves express the willingness to compare the conditions of their in-hospital schooling with those outside the hospital (Patsalis \& Darladima, 2013). The already burdened psycho-emotional state of the children functions as a further burdening factor on their unhindered learning. As we know from the international bibliography, students with chronic diseases are more likely to have behavioral problems, they internalize and transform emotions, have physical pain, develop depression and antisocial behavioral problems, have high levels of stress (Kaffenberger, 2006), as well as have aggressive behavior towards their teachers, shifting to them the negative emotions caused by the adventure of the illness and hospitalization (Patsalis \& Darladima, 2013). Therefore, the hospital teacher must not only promote learning, but also aim to encourage students and further broaden their mental capabilities (Brouskeli, 2013). In other words, he/she is called upon to normalize a situation that is extremely difficult and has a significant impact on the psychology of sick children. So, taking care of their psychological needs and preparing them for their return to the conventional school after the end of their hospitalization is extremely important. Finally, the hospital teacher must have listening skills, enhance creativity and develop self-control and adaptability (Jimenéz et al., 2019).

\subsection{State Hypotheses and Their Correspondence to Research Design}

After you have introduced the problem and have developed the background material, explain your approach to solving the problem. In empirical studies, this usually involves stating your hypotheses or specific question and describing how these were derived from theory or are logically connected to previous data and argumentation. Clearly develop the rationale for each. Also, if you have some hypotheses or questions that are central to your purpose and others that are secondary or exploratory, state this prioritization. Explain how the research design permits the inferences needed to examine the hypothesis or provide estimates in 
answer to the question.

\section{Method}

\subsection{The Aim of the Research}

The aim of this study is to highlight the institution of hospital schools and to provide the most complete description of the specific elements of the educational process in them. Of particular interest is the effectiveness of continuing the educational process during the treatment of children in the hospitals and the possibility of avoiding a further possible educational -and, consequently, social- exclusion.

\subsection{Data Collection Process}

This research is a qualitative study conducted on the basis of semi-structured interviews. The use of qualitative tools was considered ideal in order to make possible the in-depth analysis of this issue given the need to understand the complex phenomena invested in emotions and various thought processes of participants (Strauss \& Corbin, 1998).

In order to ensure a sufficient number of individuals for conducting the interviews for the purpose of the research, we used snowball sampling. Specifically, the parents' association with neoplastic diseases of N. Greece, called "LAMPSI", connected us with hospital teachers and parents of children with chronic diseases and educational experiences within the hospitals. The sample included eight teachers $(2$ males and 6 females, with teaching experience from 1 to 27 years), five of whom serve or have previously served as hospital teachers at the two pedo-oncology clinics in Thessaloniki, located in "Hippocratio" and "AHEPA" Hospitals, and three regular teachers who serve in conventional schools and had students with chronic diseases in their classrooms. Two of the latter ones had also had experienced on home teaching, at the same time with the reintegration process in the regular school classroom.

Additionally, the sample included fifteen parents, nine of whom were mothers, four were fathers and one interview was given by a couple (mother and father). All of them had children (twelve were males and three were females) who had been hospitalized in the hospitals mentioned above, and their specific characteristics are presented on the Tables $1 \& 2$ bellow.

Table 1. The chronic diseases which the children suffered from

\begin{tabular}{ll}
\hline Lymphoblastic Leukemia & 7 children (5 males/2 females) \\
Non-Hodgkin lymphoma & 3 children (all males) \\
Osteosarcoma & 2 children (1 male/ 1 female) \\
Hodgkin lymphoma & 1 child (male) \\
Glioblastoma & 2 children (both of them males) \\
\hline
\end{tabular}

Table 2. Children presentation according to their age 


\begin{tabular}{lcl}
\hline $\begin{array}{l}\text { Children's age when they were } \\
\text { diagnosed in cancer }\end{array}$ & $\begin{array}{l}\text { Children's age when the interviews were } \\
\text { conducted }\end{array}$ \\
\hline 10.5 & 19 \\
6 & 20 \\
7 & 26 \\
11 & 18 \\
4.5 & 19 \\
9.5 & 24 \\
10 & 18 \\
8 & 13 \\
9 & 13 \\
11 & 22 \\
6.5 & 7.5 \\
5 & 14.5 \\
4 & 9.5 \\
4 & 7 \\
12 & 18 \\
\hline
\end{tabular}

The data collection tool used for the research was an improvised and semi-structured interview questions, the main axes of which emerged from the review of the existing literature and from informal interviews, in the form of discussion, that were conducted with the selected people/informants during the pilot research process that preceded the main research process (Robson, 1993).

After the preparation of the questionnaire, the interviews with the hospital teachers took place within the premises of the hospital schools of the pedo-oncology and pediatric department of the "Hippocratio" Hospital. The place of the interview also allowed the researchers to have an experience of the special conditions of the daily life of the children and the teachers inside the hospital. Interviews with parents were conducted at their home or online, via Skype (see Hanna, 2012).

\section{Results}

The contents of the interviews, after their recording, were analyzed through the method of qualitative content analysis, with the "subject" as a unit of recording (Tsiolis, 2014). From the content analysis emerged three main axes, which composed a number of thematic categories and subcategories of the analysis. The above axes had to do with the education in the hospital and its continuation after leaving the hospital (both at home and during the reintegration of children in the typical school system). Obviously, in the strict context of an article, it is not possible to extend the discussion to the full range of topics that were initially explored. Therefore, we will focus on the discussions that emerged from the research and deal with the first part that refers, as we have said, to the reality of the education of children during their hospitalization. The case of home schooling and the reintegration of children into the formal educational system after their discharge from the hospital are expected to be the subjects of 
another publication in the future. Below, the axis and the corresponding thematic categories and subcategories are briefly presented with indicative extracts from the interviews, of the teachers and parents separately, outlined in two different tables (see Tables 3 and 4).

Table 3. Axes - Thematic Categories - Excerpts from interviews with parents

\begin{tabular}{|c|c|c|c|}
\hline Axe & $\begin{array}{l}\text { Thematic } \\
\text { Categories }\end{array}$ & Sub categories & Interview Excerpts \\
\hline \multirow{5}{*}{$\begin{array}{l}\text { A1. } \\
\text { Hospital } \\
\text { Education }\end{array}$} & \multirow[t]{4}{*}{$\begin{array}{l}\text { A1.1. Educational } \\
\text { structures and } \\
\text { conditions within } \\
\text { the hospital }\end{array}$} & $\begin{array}{l}\text { A1.1.1. Difficulties } \\
\text { due to treatment }\end{array}$ & $\begin{array}{l}\text { "The kids in there are dazed from all } \\
\text { the drugs. They affect. What can they } \\
\text { do? It's very difficult in there. You } \\
\text { cannot attend classes. The teachers } \\
\text { are there mostly, I believe, to keep } \\
\text { them preoccupied" (int. 15) }\end{array}$ \\
\hline & & $\begin{array}{l}\text { A1.1.2. Difficulties } \\
\text { due to } \\
\text { infrastructure }\end{array}$ & $\begin{array}{l}\text { "First of all, there was a school, in } \\
\text { quotation marks the term school. It } \\
\text { was a very poorly designed space, a } \\
\text { corridor, I would say. Fortunately, this } \\
\text { is not the case now, because the whole } \\
\text { children's department has been } \\
\text { renovated, but the school itself, I say } \\
\text { again in quotation marks, does not } \\
\text { impel the child to go in and have } \\
\text { lessons with the teacher. So, the } \\
\text { school space was negative in itself } \\
\text { "(int. 2). }\end{array}$ \\
\hline & & $\begin{array}{ll}\text { A1.1.3. Hospital } \\
\text { teachers }\end{array}$ & $\begin{array}{l}\text { "Yes, they were special education } \\
\text { teachers. The 'Hippocratio' Hospital } \\
\text { had two teachers. One was a special } \\
\text { education teacher for primary school } \\
\text { children and there also was a } \\
\text { kindergarten teacher (...)" (int. 11). }\end{array}$ \\
\hline & & $\begin{array}{l}\text { A1.1.4. Learning } \\
\text { gaps }\end{array}$ & $\begin{array}{l}\text { "We had a lot of gaps and I believe } \\
\text { that in some courses he never got it! } \\
\text { In some Mathematics courses, he was } \\
\text { left behind... and in the Ancient Greek } \\
\text { course. The lessons he had to learn by } \\
\text { heart, he had no problem with, but in } \\
\text { Ancient Greek and Mathematics, he } \\
\text { had several problems! He also had a } \\
\text { two-years break in between, when a } \\
\text { lot of things are being learnt " (int. } \\
\text { 15). }\end{array}$ \\
\hline & A1.2. & A $\quad 1.2 .1$. & "For me, the school should not be a \\
\hline
\end{tabular}




\begin{tabular}{|c|c|c|}
\hline $\begin{array}{l}\text { Disadvantages of } \\
\text { hospital education }\end{array}$ & $\begin{array}{l}\text { Special Education } \\
\text { factor/Exclusion } \\
\text { Issues }\end{array}$ & $\begin{array}{l}\text { special education school. It should } \\
\text { not! I do not think that any special } \\
\text { knowledge is required for a teacher to } \\
\text { deal with this situation. It is a child } \\
\text { who, simply, is sick, who is ill! How } \\
\text { many times have teachers not dealt } \\
\text { with children with a health problem?" } \\
\text { (int. 2) }\end{array}$ \\
\hline $\begin{array}{l}\text { A1.3. Advantages } \\
\text { of hospital } \\
\text { education }\end{array}$ & $\begin{array}{l}\text { A1.3.1. Islets of } \\
\text { freedom/ Bridges } \\
\text { with life }\end{array}$ & $\begin{array}{l}\text { "He received training for a month and } \\
\text { it was something he was looking } \\
\text { forward to every day with great } \\
\text { longing, from the moment he had } \\
\text { managed the physical problems that } \\
\text { afflicted him in which both the nurses } \\
\text { and the teachers helped a lot, so to } \\
\text { speak, to overcome. The teachers } \\
\text { would come and take the children one } \\
\text { by one from their room but first would } \\
\text { converse with them on how they were } \\
\text { doing, there was a lot of humor, a lot } \\
\text { of optimism. They would mention } \\
\text { various things so that the child could } \\
\text { forget about this whole situation and } \\
\text { slowly lead it to the school, to the } \\
\text { room that functioned as a school. Ehh, } \\
\text { it was something, a big breath in the } \\
\text { day of a child» (int. 1). }\end{array}$ \\
\hline \multirow[t]{2}{*}{$\begin{array}{l}\text { A1.4. Educational } \\
\text { practices during } \\
\text { hospitalization }\end{array}$} & $\begin{array}{l}\text { A1.4.1. } \\
\text { practices }\end{array}$ & $\begin{array}{l}\text { "Basically, because he was a small } \\
\text { child, he tried to involve him in the } \\
\text { lessons, not do reading and things like } \\
\text { that. Hands-on, mathematics, art. } \\
\text { Through painting to learn to write his } \\
\text { name. With questions: what's his } \\
\text { name, how's he doing, what does he } \\
\text { like. That is, things to preoccupy him } \\
\text { with. Through this, you can pass the } \\
\text { pedagogical element to the child so } \\
\text { that he does not stay behind and form } \\
\text { gaps" (int. 14). }\end{array}$ \\
\hline & $\begin{array}{l}\text { A1.4.2. } \\
\text { practices }\end{array}$ & $\begin{array}{l}\text { "I think they are not involved. I find } \\
\text { the hours that they come from 9am to } \\
12 \mathrm{pm} \text { the kids are not able to go out at } \\
\text { that time. At that time, from } 9 \text { to } 12 \text {, }\end{array}$ \\
\hline
\end{tabular}




\begin{tabular}{|l|l|}
\hline 1 & $\begin{array}{l}\text { treatments are done. Rather, } \\
\text { treatments and tests. MRI scans, } \\
\text { doctors pass by and visit the children. } \\
\text { I think that if the school was in the } \\
\text { afternoon or had extended hours, i.e. } \\
\text { from 4pm onwards, when the hospital } \\
\text { is quieter and the children are bored } \\
\text { out of their minds, this might have } \\
\text { been more effective, even if they only } \\
\text { worked for 4 hours as they usually } \\
\text { workfor» (int. 13). }\end{array}$ \\
\hline
\end{tabular}

Table 4. Axes - Thematic Categories - Excerpts from interviews with teachers

\begin{tabular}{|c|c|c|c|}
\hline Axes & $\begin{array}{l}\text { Thematic } \\
\text { Categories }\end{array}$ & Sub categories & Interview Excerpts \\
\hline & $\begin{array}{l}\text { B1.1 } \\
\text { General Context }\end{array}$ & $\begin{array}{lr}\text { B1.1.1. } & \text { Hiring } \\
\text { Process/ } & \text { Teaching } \\
\text { Program/ } & \text { Hospital } \\
\text { Teacher Tenure }\end{array}$ & $\begin{array}{l}\text { "-Do you know what the process is of } \\
\text { selecting teachers in hospital } \\
\text { schools? } \\
\text { - There is no process. It is like any } \\
\text { normal teaching position that is given } \\
\text { and it is an organic post, whoever has } \\
\text { the most points can get it"(int. 17). }\end{array}$ \\
\hline & 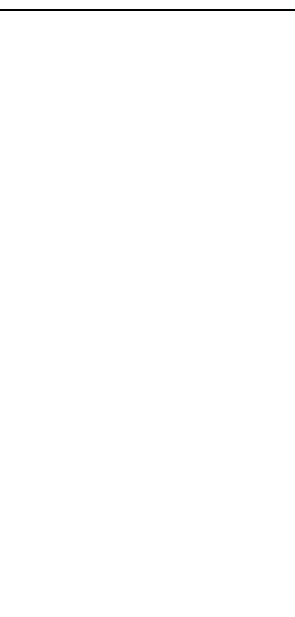 & $\begin{array}{l}\text { B1.2.1. Difficulties } \\
\text { due to treatment }\end{array}$ & $\begin{array}{l}\text { "Do you think it is important for a } \\
\text { teacher to remain in this position for } \\
\text { many years? } \\
\text {-I think it is important to take breaks } \\
\text { every few years, every three years, } \\
\text { every five years... So that he/she can } \\
\text { unload regularly. I consider it to be } \\
\text { an environment that, in the long run, } \\
\text { may be emotionally burdensome "(int. } \\
\text { 16). }\end{array}$ \\
\hline $\begin{array}{l}\text { B1 } \\
\text { Hospital }\end{array}$ & $\begin{array}{l}\text { B1.2 } \\
\text { Disadvantages } \\
\text { of hospital } \\
\text { education }\end{array}$ & $\begin{array}{l}\text { B1.2.2. Difficulties } \\
\text { due to infrastructure }\end{array}$ & $\begin{array}{l}\text { "Do you receive any teaching } \\
\text { material from the Ministry of } \\
\text { Education?" } \\
\text {-NOTHING! We make what we }\end{array}$ \\
\hline
\end{tabular}


Education

believe will help us. Nothing". (int.21).

"-What are the problems you have identified during your experience with hospital experience?

-Lack of resources, lack of material. Lack of space. These are the things" (int. 16).

"There were gaps because until we got to the point of having this communication (via the internet), the child went through a lot. There was a

B1.2.3. Learning Gaps very long time period away from the lessons and therefore, gaps were created. E, so this had an effect "(syn. 22).

"Look, it's a shock. That you enter the B1.2.4. Managing Mourning hallway and see the room empty. Empty or closed with a ribbon because it is being disinfected. It is something that is not easy to manage. But it's a bet you put with yourself. That is, you ask: "Can I endure it or not?" It's a thing, how can I explain...you sit in front of what is happening to you. It is not easy to manage "(int.19).

"They belong to special education.

B1.2.5. The Special Education factor/Exclusion Issues
From the moment the child starts the treatment, it enters this realm and stays there for a long time, it is not the same child. The doctors say it too, with the medicines etc. I see it change. Its patience changes, its concentration changes, its memory 


\begin{tabular}{|c|c|c|}
\hline & & changes" (int. 17). \\
\hline $\begin{array}{l}\text { B1.3. } \\
\text { Advantages of } \\
\text { hospital } \\
\text { education }\end{array}$ & $\begin{array}{l}\text { B1.3.1. Islets of } \\
\text { freedom/ Bridges } \\
\text { with life }\end{array}$ & $\begin{array}{l}\text { "... There are also objective } \\
\text { difficulties. When you have these } \\
\text { chemotherapies hanging around you, } \\
\text { you find it difficult to get out of the } \\
\text { room. So, the intervention takes place } \\
\text { inside the room, where you have to } \\
\text { have a different approach. That is, to } \\
\text { be the person who will play with the } \\
\text { child, who will converse with it. You } \\
\text { need to help the child understand that } \\
\text { their reintegration into school is } \\
\text { about gaining their trust in you and } \\
\text { that you will lead it there. No one else } \\
\text { will" (int. 19). }\end{array}$ \\
\hline $\begin{array}{l}\text { B1.4 } \\
\text { Educational } \\
\text { practices during } \\
\text { hospitalization }\end{array}$ & $\begin{array}{l}\text { B1.4.1. } \\
\text { Practices }\end{array}$ & $\begin{array}{l}\text { "I teach all the school subjects to } \\
\text { them. What I pay special attention to } \\
\text { is to have a lot of hands-on material. } \\
\text { A multi-sensory teaching method that } \\
\text { is. So that it is not boring. That is, I } \\
\text { cannot have a child who is } \\
\text { hospitalized and is in bed incubated } \\
\text { with its hand, the specific hand that } \\
\text { undergoes dialysis, to write. So, this } \\
\text { kid has to have a lot of performances. } \\
\text { I cannot do a lesson with a plain, dull } \\
\text { book. His stimuli must be alternated } \\
\text { so that the lesson becomes enjoyable } \\
\text { and he can absorb what I am saying. } \\
\text { Because otherwise it will be very } \\
\text { boring" (int. 21). }\end{array}$ \\
\hline
\end{tabular}

\section{Limitations and Obstacles in the Research Process}


One of the main limitations of the research process is the type of research itself. It is based on retrospective descriptions and personal confessions. This causes the discussion to have a subjective context, which is expected, however, as this is a qualitative research based on personal (and therefore subjective) narratives of people. No matter the different strategies that can be adopted, reliability cannot be ensured in qualitative researches. Not at least at the same level as the quantitative ones.

Another significant obstacle was the intense emotional state of some interviewees which prevented the smooth conduct -and in some cases even the completion- of the interviews, due to their inability to recall and relive a traumatic event. This fragility contributed to the reduction in the number of the originally scheduled interviews.

Then follows an extensive presentation and discussion of the contents of the above tables, quoting further excerpts from the interviews and commenting on them according to the existing literature.

\section{Discussion}

The relevant literature states that students with chronic illnesses are likely to experience a variety of primary and secondary adverse effects due to long-term hospitalization and medical conditions affecting their physical, psychosocial, and academic functioning (Katz \& Madan-Swain, 2006 Georgiadi \& Kourkoutas, 2010). Indeed, interviews with both parents and teachers made it clear that the children, during their hospitalization, experienced serious side effects, due to the medication they were receiving, but also from the general strain of the illness. This fact made it difficult for the educational process to run smoothly. Characteristically, one teacher states:

"... (Child's name), his mother told me, he'd either have a fever or vomit or he would not be able to get up. So how could he listen to Grammar or do Mathematics? " (int. 23).

However, apart from the problems that a student may face on a cognitive level, during hospitalization, there are also mental transitions. In an earlier study of students with cancer, participants identified and talked about the experiences of loneliness and frustration they had during their hospitalization, while also describing the differences between their conventional schools and that within the hospital (Boles et al., 2017). The researchers concluded that children with cancer are sensitive to the social and cultural differences between their school experiences and those related to hospitalization and treatment.

However, the difficulties mentioned above do not completely suppress the children's desire to receive an education during their hospitalization. Specifically, when asked if the children had sufficient physical endurance to keep up with the lessons, a hospital teacher stated:

"They keep up. Of course, they can keep up! (...) They are waiting for me anxiously to get in to do a lesson! (...) I think I did too little! I could have done much more, but simply, they did not provide me with the materials I wanted" (int. 21).

We should rather say that every child during hospitalization presents different needs in terms of his/her spiritual and educational activity. Let us not forget, after all, that each body 
responds differently to the medication given. Therefore, we will agree with Charitos and Kontadaki (2013) that a percentage of students attend the school program unhindered during their stay in the hospital, while others fail to concentrate or trust their hospital teacher.

Similar to the above concern is the issue of teaching methods followed by hospital teachers. Strong differences were recorded in the views of teachers. More specifically, some consider that children, during their hospitalization, are not able to receive teaching and, therefore, it is not necessary to aim at achieving learning outcomes. They even claim that the school space in the hospital is offered to relax from the stress of the treatments. Unlike other teachers, who believe that the above practice does not prepare children for their future school career when they return to regular school and, therefore, does not serve the purpose of education. The following contradictions are characteristic:

"For us, in general, the goal of hospital schools is not formal learning. It is for the children to come to an environment that suits them and attracts them It is to get them out of the room, which is the main target, because it is difficult to get them out of there. You have to go in again and again and find ways to entice the children and bring them into the school. Our goal, therefore, is to get the children out of the room, to be able to bring them to the school and make them happy. The goal is not for them to learn. This is not our part" (int. 20).

"Well, everyone thinks lessons should be done. I have broken that standard. If a child wants to do lessons, yes, it will! I can't force it, though. I'm interested in the child getting out of bed. As long as I am here, he/she is able to work on what he/she can. We have children who knew a few letters and yet managed, without having a strict school curriculum, to read. Using games!" (int. 17).

"If the child really has the opportunity to attend school at a pediatric oncology clinic, I think that the school should have the same high goals and the same high expectations from an ill child as it does from a typical child who is not hospitalized. And I say this, not in the sense of the pressure to complete the curriculum or that things have to be done for didactic reasons. But, mainly because, they have to be done for pedagogical reasons! I think that the child who is unwell and hospitalized, of course, not all days are the same; some of the days will be very difficult. But there are many days, because they are hospitalized for too long, that the children not only feel capable and, in the mood, but, most importantly, they are able and we must give them what they would have, if they were attending a formal class (...) I believe that there must be goal setting. Surely, the goals will be different (...) but this will create a routine, a normalcy, so to speak, for his/her living in the hospital. It will have a routine, that "I will go to school, I have to study, I learned this, I learned that" and not "I go to school to paint or do crafts". So aimless and pointless ... That is, I think that somehow all this hides a sense of pity and this is not fair for these children, who are struggling during this phase for their own lives, to pity them. I think they want us to support them for the future" (int. 18).

The parents, however, did not show similar discrepancies like the teachers. They all agreed that typical teaching was not provided during the hospitalization of their children.

"Lessons, lessons, by definition, as done in school, they did not do! Initially, they did crafts, 
paintings, read stories, fairy tales "(int. 5).

"They rarely come into the rooms to do some lessons or to preoccupy them or do some crafts and, perhaps, do something alternative, as a way of educating" (int. 13).

Another issue that raises concerns has to do with the schedule of teachers in hospital schools. As two hospital teachers informed us, these schools follow the schedule of the typical primary schools:

"Whatever applies to all schools, also applies to hospital schools. Our school, of AHEPA, belongs to the Primary Education (...)" (int. 16).

"Typically, it is a school that belongs to the Ministry of Education, so there are working hours here as well. For example, I come here at 9:00am and I get off at 12:20pm. I am always in the office from 8:00 in the morning. Because there are no breaks, in the classical sense" (int. 17).

Knowing that all the diagnostic tests and the visits of the doctors to the rooms take place in the morning, it is reasonable to think about how feasible the morning function of the hospital school becomes. Obviously, the schedule of these schools can only be incomplete, in relation to the schedule of the schools that function under normal conditions. This fact leads to the belief that there is no serious involvement of the State for the proper functioning of these schools, as it places them in a context that does not meet the special needs and reality of the children who are hospitalized. A teacher characteristically states:

"They are not covered [the needs of the children]. And this is tragic! Really tragic! Because the school inside the clinic is a reference point (...) They wait to come, because we make very nice things and, in the summer, this stops and the children are left behind in the educational process. And in the afternoons, the same! Because, in the afternoon, in a clinic, either in an oncology one or pediatric one, because I've been in there a few times, it is an absolute desert! And from all the children, this is what I'm told, that: "the afternoon is very difficult, Ms.". That's why I'm building a lending library for all ages. I lend them a lot of books. I lend them board games. I leave them with a lot of materials, so that they have something to do. An afternoon shift is definitely needed!" (int. 20).

As for the hospital teachers, we must emphasize that this is a special group of educators. They work in a very demanding and emotionally charged environment with many responsibilities, where they do not exclusively have the luxury of conducting teaching. Brouskeli (2013) emphasizes that hospital teachers are significantly different from teachers in formal schools. Not only do they promote learning, but they also work on encouraging children and offering them satisfying experiences. Quoted by a hospital teacher:

"It is a multifaceted thing that the teacher should combine so that he/she can find ways in which the work will be done as a whole and in between. And the work is layered, it's a lot; it is not just the part of learning. You leave it aside for a while. Mostly, it is the way not to let the child get lost in school activity, but also to prepare it for later" (int. 19).

Also, precisely because the hospital teacher is faced with many challenges daily -such as the 
number of children, their different ages and their different educational abilities and needswhich are very likely to change in cases of frequent departures of some or new inductions of others to the hospital, the flexibility of the daily teaching process is considered necessary. Hospital teachers are asked to create lesson plans that are profoundly interesting and short in duration (Murphy \& Ashman, in: Brouskeli, 2013). Moreover, the existence in the same class of children of different ages and levels of learning, points to the need to expand the discussion towards a direction of inclusion in the daily process of teaching methods used in the particular case of small multi-staged rural schools. We are talking about the adoption of the Lancasterian (a kind of peer-to-peer) teaching method or other alternative collaborative peer tutoring models, which might, perhaps, offer a solution in the case of hospital education. Therefore, teachers with many years of experience in rural schools could be particularly useful in implementing respective teaching practices.

The increased demands and the pervasive pain and, sometimes, an experienced mourning from the possible loss of life of some students, often seem to lead to additional emotional burden on the hospital teachers, a fact that is reflected in their short stay in these positions. One teacher mentions:

"I changed departments because of this reason. Because I think that in oncology, when I was there for three years, I had reached a certain level of mental capacity in order to endure some things. Therefore, I came to pediatrics, wanting to gain strength" (int. 20).

It has to do with a burn-out syndrome, perhaps more justified in this case of hospital schools than in typical ones. In the latter, this syndrome is frequently questioned and deduced to an attempt to rationalize the given inefficiency of our educational system and a -possibly unconscious- transfer of responsibilities to students, that is, to the victims of the educational process (see Bairaktaris, 2008; Leontari, Kyridis, Gialamas, 1997; Leontari, Kyridis, Gialamas, 2000; Zagkos, Kamarianos, Kyridis, Fotopoulos, 2020). However, some do not accept similar rationalizations, not even in the case of hospital schools, arguing that teachers should remain in their positions for as long as possible and, at the same time, plan as best as they can (Vasilatou-Kosmidi, 2013b). It is worth noting at this point the extremely insufficient training offered to teachers of hospital education, in the context of their circular studies while attending the Pedagogical Departments. This fact was confirmed to us by the teachers themselves who took part in the research. The hospital schools of Thessaloniki constitute an exception, as the filling of their positions is required to be done by Special Educators, since the specific hospitals are included in the sector of Special Education. To the question, then, if they have been taught in their circular studies corresponding courses for hospital education, the answers were all negative, such as the following:

"To tell you the truth, the university has no idea of what is going on. Nobody knew the slightest thing! Because I took some special courses, out of necessity. When I left the hospital, I dealt with cerebral palsy. And in some courses, the long 600 hours we did, neither the instructors nor the teachers themselves, who were with us in the groups, knew what this thing was. What is a hospital school...? They do not know (...) The point is that there are not enough teachers to deal with such issues. And we, who graduated the School of Pedagogy, I 
do not know what is happening now in the Department of Special Education, no one, but no one, told us about these schools! In fact, no one knows what these schools are! What are the special teaching conditions in these schools? What are the special qualifications of teachers..." (int. 19).

Similarly, another teacher states the following:

"This whole sector should be part of our circular studies. I consider it very basic. Why, have we never heard anything like this... I, for the first time, remember, when I heard that there was a teacher in the hospital, I wondered: "What teacher is he? From a private school? Is he from a public school? How did he get in?" I did not know at all what was happening!" (int. 23).

In addition, when asked if hospital teachers should be provided with a special handbook from the Ministry of Education that prepares them, at least on a first level, on hospital education and the difficulties they face, the response was sharp:

"It would be good to have it done, but by whom? This manual can be made by the ministry, in cooperation with hospital teachers. Because, they know. No one can understand what it is like to work in a hospital. No one! Because when you are a hospital teacher, you are not only that. You are a psychologist, you are a social worker, you support the parents a lot. And this part is huge! " (int. 19).

The above assumptions are confirmed by Capurso \& Vecchini (2010), who study hospital education in Italy and describe a similar situation, emphasizing that a teacher's professional contribution to a hospital addresses both health and education issues. Despite this complexity, the initial training of teachers working in hospitals includes minimal information on health, communication in stressful situations and the psycho-pedagogical protection of sick children.

Similar is the lack of knowledge regarding the possibility of using the technology offered today, in order to ensure distance learning participation of children who are hospitalized in the daily teaching procedures of their regular classes. The inadequacy is particularly tragic at a time when the ministry is requiring distance education, due to the current SARS-CoV-2 pandemic, to all schools in the country. There were, of course, from time to time some teachers who, on their own initiative, incorporated in their daily teaching practice some form of similar technology, which allowed the internet connection of their class with their hospitalized student. Specifically, some mothers mentioned:

"Our teacher, because he was tech-savvy, had a camera installed. We Skyped (...) He thought that it would be very good for children to see... (child's name) and his development, because it is very shocking for a child to see a classmate, suddenly, completely changed! Because our child's face had completely become altered. Cortisone deforms. It makes you swell...So, the whole process, from how he was... (child's name) to how he had become with the use of cortisone, the children saw it as normal, because they'd see him every day" (int.9).

"Personally, the teacher and I, once we said that we will do a Viber lesson (...) even for a while, something happened! He had live contact, let's say, via Viber at that time "(int. 11). 
The relevant bibliography also shows that in the case of hospital education, the use of technology effectively aids teaching practices. In particular, online teaching practices are encouraged for children who are hospitalized or confined at home for long periods due to an illness (Trentin, 2013). Also, Ferrara \& Flammia (2013) report on a system called "tele-class" and has been successfully tested in various hospitals in Italy, allowing the child to communicate with the outside world in a very simple and easy way. The effectiveness of the child's internet connection with his previous school is pointed out by a teacher in our research:

"It helped a lot that, during the time that there was this contact, the internet connection coincided with the end of the year to do a play. There, as he was absent all year... During the play, the rehearsals were done at home. The parts that the child himself played, the rehearsals were done both on their own and with internet connection. This play, therefore, was the occasion for him to come into contact with children in an active way for the first time after his illness. So, when he came to that play, he did not come for class, he did not come into the classroom. He came to perform! This, has maybe helped so much, that the child has now overcome his fears" (int. 22).

In conclusion, we could say that a coordinated effort of cooperation of all participants -parents, hospital teachers and regular school teachers- is necessary and extremely important in the formation of a holistic plan to address this demanding issue, combining new ways of teaching and communication for as long as the child is away from school. This entails the substantial contribution of the state, on the basis of becoming very engaging with this issue, in order to make possible the organization of an elaborate reintegration system that prevents situations of educational and social exclusion and at the same time informs the whole society about the dimensions of this extremely sensitive issue, the hospital education of children with chronic diseases. However, we must keep in mind that the proposal above should not be generalized to all schools with no discretion. In such a case, it would be damaging for the necessary freedom and the pedagogical relationship within the teaching procedure, since it would likely be transformed to a very suspicious mean of surveillance and social control.

\section{References}

Arabatzi, V., \& Tourtouras, Chr. (2015). Educational exclusion of children with health problems. The institution of "hospital schools". In: P. Georgogiannis (Ed.), Social Pedagogy, Interculturalism and Special Education I. Patra: 18th International Conference, 83-98.

Bäckman, O., \& Nilsson, A. (2011). Pathways to Social Exclusion - A Life-Course Study. European Sociological Review, 27(1), 107-123. https://doi.org/10.1093/esr/jcp064

Bairaktaris, K. (2008). Burnout: The Psychologization of Alienation. Society and Mental Health, 9, 82-89.

Benigno, V., Fante, C., Epifania, O. M., Caruso, G. P., \& Ravicchio, F. (2018). A dynamic model for distance learning: evaluation of an online course for hospital teachers' professional development. Italian Journal of Educational Technology, 26(1), 90-103. https://doi.org/10.17471/2499-4324/958 
Boles, J. C., Winsor, D. L., Mandrell, B., Gattuso, J., West, N., Leigh, L., \& Grissom, S. M. (2017). Student/patient: the school perceptions of children with cancer. Educational Studies, 43(5), 1-18. https://doi.org/10.1080/03055698.2017.1312288

Bourdieu, P., \& Passeron, J. C. (2014). The Reproduction. Karabelas, G. (Trans.), Athens: Alexandria.

Brouskeli, B. (2013). The experience of hospitalization and return to school: issues of education and adaptation of the child. Research in Education - Hellenic Journal of Research in Education, 1, 81-95. https://doi.org/10.12681/hjre.8793

Capurso, M., \& Vecchini, A. (2010). Un profilo professionale degli insegnanti di scuola in ospedale. L'integrazione Scolastica e Sociale, 9(5), 519-526.

Charitos, V., \& Kontadaki, T. (2013). Primary education for the hospitalized child. In V. Charitos (Ed.), School for the hospitalized child. Athens: Polygono, 57-63.

DeWall, N. C., Deckman, T., Pond, R. S., \& Bonser, I. (2011). Belongingness as a Core Personality Trait: How Social Exclusion Influences Social Functioning and Personality Expression. Journal of Personality, 79(6), 1281-1314. https://doi.org/10.1111/j.1467-6494. 2010.00695.x

Dixon-Woods, M., Young, B., \& Heney, D. (2005). Rethinking Experiences of Childhood Cancer. England: Open University Press.

EACH. (2019). https://www.each-for-sick-children.org Retrieved from https://www.each-for-sick-children.org/each-charter/the-10-articles-of-the-each-charter\#anno tation-12

Ferrara , L., \& Flammia, A. (2013). The Hospital School towards an Integrated Model of Training of Quality. American Journal of Educational Research, 1(10), 442-448. https://doi.org/10.12691/education-1-10-6

French, A.E., Tsangaris, E., Berrera, M., Guger, S., Brown, R., Urbach, S., Stephens, D., \& Nathan, P.C. (2012). School Attendance in Childhood Cancer Survivors and Their Siblings. The Journal Of Pediatrics, 162(1), 160-165. https://doi.org/10.1016/j.jpeds.2012.06.066

Georgiadi, M., \& Kourkoutas, E.E. (2010). Supporting Pupils with cancer on their return to school: a case study report of a reintegration program. Procedia - Social and Behavioral Sciences, 5(WCPCG 2010), 1278-1282. https://doi.org/10.1016/j.sbspro.2010.07.275

Gerd, F. S., \& Capurso, M. (2010). La tutela educativa di bambini e ragazzi malati in Europa: un'indagine internazionale. L'integrazione scolastica e sociale, 9(1). Retrieved from https://www.researchgate.net/publication/262563906_La_tutela_educativa_di_bambini_e_rag azzi_malati_in_Europa_un'indagine_internazionale

Hanna, P. (2012). Using internet technologies (such as Skype) as a research medium: a research note. Qualitative Research, 12(2), 239-242. https://doi.org/10.1177/146879 4111426607 
Hay, G., Nabors, M., Sullivan, A., \& Zygmund, A. (2015). Students with pediatric cancer: A prescription for school success. Physical Disabilities: Education and Related Services,34(2), 1-13. https://doi.org/10.14434/pders.v34i2.19643

Irwin, M. K., \& Elam, M. (2011). Are we leaving children with chronic illness behind? Physical Disabilities:Education and Related Services, 30, 67-80.

Isari, F., \& Pourkos, M. (2015). Qualitative Research Methodology. Applications in Psychology and Education. Athens: Association of Greek Academic Libraries.

Jimenéz, N. N., Montes, J. E., \& Alcocer, E. C. (2019). La pedagogía hospitalaria: un espacio de amor y reconocimiento para el paciente pediátrico oncológico.

Kaffenberger, C. J. (2006). School Reentry for Students with a Chronic Illness: A Role for Professional School Counselors. ASCA-Professional School Counseling, 9(3), 223-230. https://doi.org/10.1177/2156759X0500900312

Katz, E. R., \& Madan-Swain, A. (2006). Maximizing School, Academic and Social Outcomes in Children and Adolescents With Cancer. In R. T. Brown (Ed.), Comprehensive handbook of Childhood Cancer and Sickle Cell Disease: A Biopsychosocial Approach. New York: Oxford University Press. https://doi.org/10.1093/oso/9780195169850.003.0023

Kyridis, A. (1996) Educational Inequality. Thessaloniki: Kyriakidis Bros.

Kyridis, A. (2003). Inequality in Greek education and access to university (1955-1985). Athens: Greece.

Kyridis, A., Tsakiridou, H., Zagkos, Ch., Koutouzis, M., \& Tziamtzi, Ch. (2011). Educational inequalities and school dropout in Greece. A regional issue. International Journal of Education, 3(2), 1-15. https://doi.org/10.5296/ije.v3i2.855

Leontari, A., Kyridis, A., \& Yialamas, B. (1997). Teachers stress. Psychological Issues, 7(3), $139-152$.

Leontari, A., Kyridis, A., Yialamas, B. (2000). The professional stress of teachers in Greek primary education. Educational Review, 30, 139-161.

Pantazis, B. (2013). The United Nations Convention on the Rights of the Child and the EACH Chart. In: V. Charitos (Ed.), School for the hospitalized child. Theoretical and Empirical approaches. Athens: Polygono, 45-56.

Patsalis, Ch., \& Darladima, I. (2013). Hospital education and the need for a proper training of the teachers who serve it. In: V. Charitos (Ed.), School for the hospitalized child. Theoretical and empirical approaches. Athens: Polygono, 65-71.

Pleios, G. (1998). The new content of social exclusion and the relationship between unemployment and education level. Sychrona Themata, 67, 73-83.

Robson, C. (1993) (1st ed.). Real World Research. U.K.: Blackwell Publishing Ltd. 


\section{Macrothink}

International Research in Education

ISSN 2327-5499

2021, Vol. 9, No. 1

Serradas Fonseca, M. (2018). Pedagogía Hospitalaria: Hacia la concreción de una Educación Inclusiva. In: Educación Inclusiva. Caracas: Ediciónes del Vicerrectorado Académico, 52-86.

Strauss, A., \& Corbin, J. (1998). Basics of qualitative research: Techniques and procedures for developing grounded theory. Thousand Oaks.

Thanos, Th., Kamarianos, I., Kyridis, A., \& Fotopoulos, N. (2017). Sociology of education. Athens: Gutenberg.

Tobia, V., Riva, P., \& Carpin, C. (2017). Who Are the Children Most Vulnerable to Social Exclusion? The Moderating Role of Self-Esteem, Popularity, and Nonverbal Intelligence on Cognitive Performance Following Social Exclusion. Journal of Abnormal Child Psychology, May, 45(4), 789-801. https://doi.org/10.1007/s10802-016-0191-3

Tourtouras, Chr. (2017) (3rd ed.). School Failure and Exclusion. Thessaloniki: Epikentro.

Trentin, G. (2013). Tecnologie di Rete e Istruzione Domiciliare (TD special issue, preface). Retrived from https://www.researchgate.net/publication/253234207_Tecnologie_di_Rete_e_Istruzione_Do miciliare_TD_special_issue_preface

Tsiakalos, G. (2008) (3rd ed.). The promise of Pedagogy. Thessaloniki: Epikentro.

Tsiolis, G. (2014). Methods and techniques of analysis in qualitative social research. Athens: Kritiki SA.

Vasilatou-Kosmidi, E. (2013a). European Standards for the Care of a Child with Cancer. (SIOP, Producer) Retrieved from file: ///Users/imac24/Desktop/European_Standards-Greek.pdf

Vasilatou-Kosmidi, E. (2013b). Hospital: a different school for the child with cancer. In V. Charitos (Ed.), School for the hospitalized child. Athens: Polygono, 25-27.

Zagkos, Ch., Kamarianos, I., Kyridis, A., \& Fotopoulos, N. (2020). The conditions of being a teacher in the Greek public educational system. Athens: Koinoniko Polykentro.

\section{Copyright Disclaimer}

Copyright reserved by the authors.

This article is an open-access article distributed under the terms and conditions of the Creative Commons Attribution license (http://creativecommons.org/licenses/by/4.0/). 